\title{
Pengaruh mikronutrien taburia terhadap perkembangan motorik anak usia 24-48 bulan yang stunting (Studi di Tanjungkarang Barat Kabupaten, Bandar Lampung)
}

\begin{abstract}
Arie Nugroho ${ }^{1}$, Hardhono Susanto ${ }^{2}$, Martha I. Kartasurya ${ }^{3}$
ABSTRACT

Background: Stunting is associated to the developmental delays of gross motor and fine motor skills. Previous studied state that micronutrient supplementation has a positive effect on both motor skills development in children aged under 24 months. Objective: The aim of this study was to analysis the effect of micronutrient sprinkle on motor development among stunted children aged 24 to 48 months.

Methods: A quasi-controlled experimental group study with a total of 63 stunting age 24-48 months are divided into treatment group (31 children) and controls (32 children). Treatment group received micronutrient sprinkle supplementation once in two days for two months. Fine and gross motor development was measured by DDST II before and after intervention.

Results: There was no difference in age, sex, energy intake, protein, zinc, folic acid and developmental delay percentage before treatment. The percentage of fine motor delays before treatment was $48.4 \%$ in the treatment group and $53.1 \%$ in the control group, while the percent of gross motor delay was $32.3 \%$ in the treatment group $34.4 \%$ in the control group. After intervention, the percentage of fine motor developmental delays significant decreases $25.8 \%$, in the treatment group and $34.4 \%$ in the control group, while the percentage of gross motor delay in the control group significant decreased to $12.5 \%$, but not significant decreased to $16,1 \%$ in the treatment group. Confounding variables in this study were include energy adequacy level, protein adequacy level, zinc, iron and folic acid. There was no differences percentage of developmental delays on fine motor $(p=0,514)$ and gross motor $(p=0,571)$ after the intervention and after controlling with confounding variables.

Conclusion: Micronutrient sprinkle supplementation for two months did not influence the development of fine motor skills gross motor skills on stunting preschooler children age 24 to 48 months
\end{abstract}

Keyword: fine motor skills, gross motor skills, stunting, preschool children, sprinkle micronutrient.

\section{ABSTRAK}

Latar belakang: Keadaan stunting berhubungan dengan keterlambatan perkembangan motorik kasar dan motorik halus. Studi sebelumnya menunjukkan suplementasi mikronutrien berefek positif pada kedua perkembangan motorik anak usia dibawah 24 bulan.

Tujuan: Menganalisis pengaruh pemberian sprinkle mikronutrien terhadap perkembangan motorik anak pendek usia 24 - 48 bulan.

Metode: Penelitian kuasi eksperimen dengan subjek sebanyak 63 anak usia 24 - 48 bulan yang pendek. Sebanyak 31 anak sebagai kelompok perlakuan dan 32 anak kelompok kontrol. Kelompok perlakuan mendapat sprinkle mikronutrien 2 hari sekali selama 2 bulan. Perkembangan motorik kasar dan morotik halus diukur dengan kuesioner deteksi tubuh kembang Denver Tes II sebelum dan sesudah intervensi.

Hasil: Tidak ada perbedaan usia, jenis kelamin, asupan energi, protein, seng, asam folat dan perkembangan sebelum perlakuan. Persentase keterlambatan motorik halus sebelum perlakuan adalah 48,4\% pada kelompok perlakuan dan 53,1\% pada kelompok kontrol, sedangkan persen keterlambatan motorik kasar adalah 32,3\% pada kelompok perlakuan 34,4\% pada kelompok kontrol. Setelah intervensi, persentase keterlambatan perkembangan motorik halus signifikan menurun 25,8\%, pada kelompok perlakuan dan 34,4\% pada kelompok kontrol, sedangkan persentase keterlambatan perkembangan motorik kasar pada kelompok kontrol signifikan menurun menjadi 12,5\%, namun tidak signifikan menurun menjadi 16,1\% pada kelompok perlakuan. Variabel diduga sebagai perancu dalam penelitian ini adalah meliputi tingkat kecukupan energi, protein, seng, besi dan asam folat. Tidak ada perbedaan persentase keterlambatan perkembangan motorik halus $(p=0.514)$ dan motorik kasar $(p=0.571)$ setelah intervensi dan setelah mengendalikan dengan variabel pengganggu.

Simpulan: suplementasi sprinkle micronutrien selama dua bulan tidak mempengaruhi perkembangan motorik halus dan motorik kasar pada anak stunting 24 sampai 48 bulan

Kata kunci: perkembangan motorik halus, motorik kasar, stunting, anak 24 - 48 bulan, sprinkle mikronutrien.

\section{PENDAHULUAN}

\footnotetext{
${ }^{1} J u r u s a n$ Gizi, Politeknik Kesehatan, Tanjungkarang, Indonesia

${ }^{2}$ Dosen Fakultas Kedokteran Universitas Diponegoro, Indonesia

${ }^{3}$ Dosen Fakultas Kesehatan Masyarakat, Universitas Diponegoro, Indonesia
}

Stunting menyebabkan terhambatnya perkembangan motorik kasar maupun halus, karena pada anak stunting terjadi keterlambatan kematangan sel-sel saraf terutama di bagian cerebellum yang merupakan pusat koordinasi gerak motorik. ${ }^{1}$ Penurunan fungsi 
motorik anak stunting tanpa kelainan bawaan berkaitan dengan rendahnya kemampuan mekanik dari otot tricep surae sehingga lambatnya kematangan fungsi otot tersebut menyebabkan kemampuan motorik anak stunting terhambat. ${ }^{2}$ Penelitian mengenai pemberian vitamin maupun mineral di beberapa negara memiliki efek yang positif terhadap perkembangan motorik anak. . $^{3-7}$

Pemberian Taburia difokuskan pada balita dengan rentang umur 6 sampai 24 bulan dengan pertimbangan pada usia tersebut merupakan periode emas pertumbuhan. ${ }^{7}$ Pada keadaan normal mielinasi pada daerah otak yang berhubungan dengan koordinasi tangan dan mata tidak lengkap hingga anak berusia sekitar empat tahun. ${ }^{8}$ Setelah anak berusia lebih dari empat tahun, pertumbuhan susunan saraf berlangsung lebih lambat. ${ }^{9}$ Anak yang mendapat perlakuan beberapa micronutrient setiap minggu selama tujuh bulan memiliki skor perkembangan motorik lebih baik dibanding yang tidak. ${ }^{6}$ Pemberian micronutrient sprinkle dengan nama Taburia selama dua bulan mampu menurunkan persentase keterlambatan perkembangan motorik halus pada anak stunting usia 12-36 bulan di kota Semarang. ${ }^{10}$

Hasil Riset Kesehatan Dasar tahun 2010 menunjukan Provinsi Lampung memiliki prevalensi balita stunting sebesar 36,2\% yang terdiri dari 20,6\% sangat pendek dan 15,6\% pendek. ${ }^{11}$ Pada tahun 2012 Kota Bandar Lampung memiliki prevalensi balita pendek $17,7 \%$ dan prevalensi untuk balita sangat pendek 13,9\%. Kecamatan Tanjungkarang Barat mempunyai prevalensi balita stunting cukup tinggi di Kota Bandar Lampung dibandingkan dengan Kecamatan lain yaitu $17,9 \%$ balita pendek dan $19,7 \%$ balita sangat pendek. ${ }^{12}$ Kegiatan PAUD meningkatkan stimulasi terhadap aktivitas anak, perkembangan optimal motorik halus dan kasar dipengaruhi oleh aktivitas anak. Penelitian pada anak stunting di Jamaika menunjukkan bahwa perkembangan motorik anak lebih dengan status gizi, kemampuan motorik anak stunting hampir sama dengan dipengaruhi oleh stimulasi dibanding anak-anak normal setelah menerima stimulasi dan suplementasi. ${ }^{13}$

\section{METODE DAN BAHAN}

Desain penelitian yang digunakan adalah quasi experimental. Subjek penelitian ini adalah anak stunting berusia 24-48 bulan di Kecamatan Tanjungkarang Barat, Kota Bandar Lampung, dengan kriteria inklusi subjek tidak memiliki kelainan bawaan, tidak memiliki riwayat penyakit kronis dan telah mengikuti PAUD selama dua bulan. Subjek sejumlah 68 orang dibagi menjadi 2 kelompok, yaitu kelompok perlakuan dan kelompok kontrol. Lima subjek drop out dalam penelitian ini, sehingga total subjek penelitian yang dianalisis adalah 63 subjek.

Variabel bebas dalam penelitian ini adalah kelompok perlakuan dan kontrol. Kelompok perlakuan diberi micronutrient sprinkle 2 hari sekali dengan dosis 1gr (1 bungkus) selama 2 bulan intervensi serta dilakukan penyuluhan 2 minggu sekali untuk memotivasi ibu maupun pengasuh agar memberikan asupan makanan yang seimbang dan pola asuh yang baik kepada anak. Kelompok kontrol tidak diberikan mikronutrient sprinkle, tetapi diberikan penyuluhan yang sama 2 minggu sekali. Variabel terikat adalah perkembangan motorik kasar dan halus diukur pada sebelum dan sesudah intervensi dengan menggunakan formulir Denver Development Screening Test II (DDST II). Hasil ukur dikategorikan keterlambatan, bila didapatkan $\geq 2$ peringatan dan atau 1 keterlambatan dan dikategorikan normal jika hanya terdapat 1 peringatan dan tanpa keterlambatan.

Variabel perancu yang diteliti adalah tingkat kecukupan energi, tingkat kecukupan protein, asupan besi, seng dan asam folat. Data asupan energi, protein, seng, zat besi dan asam folat yang diperoleh dari food recall 4x24 jam pada sebelum dan selama intervensi diolah dengan menggunakan nutrisurvey seameo 2005. Data yang terkumpul akan melalui editing, coding, entry, dan verification menggunakan SPSS 16.0 .

\section{HASIL}

Subjek pada awal penelitian ini berjumlah 34 orang pada masing-masing kelompok. Tiga subjek drop out dalam penelian ini, tiga subjek dari kelompok perlakuan (satu orang berjenis kelamin laki-laki, dan dua perempuan) dan dua subjek dari kelompok kontrol berjenis kelamin perempuan. Hasil uji Chi square terhadap jenis kelamin subjek menunjukkan tidak ada perbedaan yang bermakna antara kelompok perlakuan dan kelompok kontrol dengan nilai $p=1,000$.

Karakteristik subjek penelitian ditunjukan pada tabel 1. Uji Mann-whitney terhadap umur subjek menunjukkan tidak ada perbedaan yang bermakna antara kelompok perlakuan dan kelompok kontrol. Uji Mann-whitney terhadap tingkat kecukupan energi dan uji Independent t-test terhadap tingkat kecukupan protein menunjukkan tidak ada perbedaan yang bermakna antara kelompok perlakuan dan kelompok kontrol sebelum pemberian intervensi.

Pada penelitian ini perkembangan motorik anak diukur dengan menggunakan Denver Developmental Screening Test II dan dikategorikan menjadi keterlambatan dan normal, sedangkan yang menolak untuk diukur sejak awal dikeluarkan dari subjek penelitian. Uji Chi square terhadap perkembangan 
motorik halus dan motorik kasar menunjukkan tidak ada perbedaan motorik yang bermakna antara kelompok perlakuan dengan kelompok kontrol sebelum intervensi (Gambar 2.) dengan nilai nilai $p$ berturut-turut $p=0,901$ (motorik halus) dan $p=1,000$ (motorik kasar).

Hasil uji Mc Nemar terhadap perkembangan motorik halus pada kelompok perlakuan dan kontrol berturut-turut nilai $p=0,016$ dan $p=0,031$, sedangkan hasil uji perkembangan motorik kasar pada kelompok perlakuan dan kontrol berturut-turut nilai $p=0,062$ dan $p=0,016$. Hasil ini menunjukan bahwa terdapat perbedaan yang bermakna pada perkembangan motorik halus dan motorik kasar antara sebelum dan setelah

Tabel 1. Karakteristik subjek sebelum intervensi

\begin{tabular}{lccc}
\hline \multirow{2}{*}{ Karakteristik subjek } & Perlakuan $(\mathrm{n}=31)$ & Kontrol $(\mathrm{n}=32)$ & \multirow{2}{*}{$p$} \\
\cline { 2 - 3 } & Mean $\pm \mathrm{SD}$ & Mean \pm SD & \\
\hline Umur (bulan) & $44 \pm 3,59$ & $43,4 \pm 3,96$ & $0,698^{\mathrm{b}}$ \\
Tingkat kecukupan energi (\%) & $79,6 \pm 19,84$ & $71,3 \pm 17,88$ & $0,161^{\mathrm{b}}$ \\
Tingkat kecukupan protein (\%) & $100,3 \pm 22,44$ & $104,7 \pm 26,74$ & $0,486^{\mathrm{c}}$ \\
Asupan energi/ hari (Kkal) & $1059,8 \pm 181,22$ & $1005,8 \pm 204,29$ & $0,272^{\mathrm{c}}$ \\
Asupan protein/ hari (g) & $31,7 \pm 7,59$ & $31,8 \pm 6,89$ & $0,937^{\mathrm{c}}$ \\
Asupan seng/ hari (mg) & $3,1 \pm 1,06$ & $3,2 \pm 0,84$ & $0,327^{\mathrm{c}}$ \\
Asupan besi/ hari (mg) & $2,8 \pm 1,44$ & $3,3 \pm 1,38$ & $0,226^{\mathrm{b}}$ \\
Asupan asam folat/ hari $(\mu \mathrm{g})$ & $57,4 \pm 24,71$ & $68,8 \pm 24,52$ & $0,072^{\mathrm{b}}$ \\
\hline
\end{tabular}

${ }^{\mathrm{a}}$ uji Chi square ${ }^{\mathrm{b}}$ uji Mann-whitney ${ }^{\mathrm{c}}$ uji Independent t-test
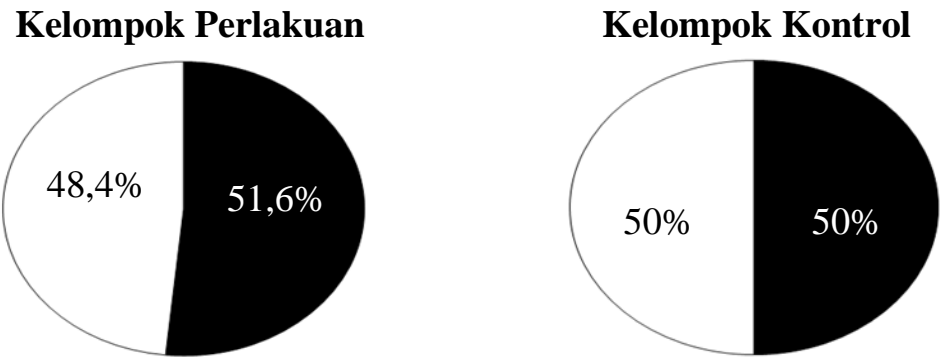

Gambar 1. Jenis kelamin subjek penelitian

Ket : $\square=$ Perempuan, $\square=$ Laki - Laki

intervensi berupa taburia yang diberikan selama dua bulan kepada kedua kelompok, baik itu kelompok perlakuan dan kelompok kontrol dikarenakan terjadi penurunan persentase keterlambatan motorik halus dan motorik kasar pada kedua kelompok. Gambar 3 menjelaskan pengaruh intervensi terhadap persentase keterlambatan perkembangan motorik.

Disimpulkan bahwa pemberian perlakuan micronutrient sprinkle dalam bentuk taburia tidak berpengaruh terhadap perkembangan motorik halus dan motorik kasar anak stunting yang mengikuti pendidikan anak usia dini (PAUD), dikarenakan terdapat perbedaan bermakna antara sebelum intervensi dan setelah intervensi pada kedua kelompok yaitu kelompok perlakuan dan kelompok kontrol.

Hasil analisis asupan zat gizi dengan uji Independent t-test menunjukkan bahwa tidak ada perbedaan yang bermakna rata-rata asupan energi dan asupan protein antara kelompok perlakuan dan kelompok kontrol setelah intervensi. Hasil analisis asupan zat gizi menunjukkan bahwa terdapat perbedaan yang bermakna rata-rata asupan seng, besi dan asam folat antara kelompok perlakuan dan kelompok kontrol setelah intervensi. Rerata tingkat kecukupan energi, tingkat kecukupan protein, ratarata asupan energi, protein, seng, besi, asam folat pada kelompok perlakuan dan kontrol setelah intervensi micronutrient sprinkle bentuk taburia (Tabel 2).

Pemberian intervensi berupa micronutrient sprinkle dalam bentuk taburia berpengaruh terhadap asupan zat gizi mikro subjek dalam hal ini terkait dengan peningkatan rata-rata asupan seng, besi dan asam folat pada kelompok perlakuan. Hasil uji Wilcoxon pada tingkat kecukupan energi sebelum dan setelah intervensi antara kelompok perlakuan dan kontrol diperoleh nilai $p=0,001$ pada kelompok 
perlakuan artinya terdapat perbedaan tingkat kecukupan energi yang bermakna sebelum dan setelah intervensi hanya pada kelompok perlakuan, dengan kata lain intervensi dengan pemberian micronutrient sprinkle dalam bentuk taburia meningkatkan tingkat kecukupan energi subjek.

Hasil uji Paired t-test pada tingkat kecukupan protein sebelum dan setelah intervensi antara kelompok perlakuan dan kontrol diperoleh nilai $p=0,015$ pada kelompok perlakuan artinya terdapat perbedaan rerata tingkat kecukupan protein yang bermakna sebelum dan setelah intervensi pada kelompok perlakuan, dengan kata lain terjadi peningkatan pemenuhan kecukupan protein subjek. Perbedaan tingkat kecukupan energi dan protein pada sebelum dan setelah intervensi disajikan dalam Grafik 4.

Tabel 2.Tingkat kecukupan energi, tingkat kecukupan protein dan rata - rata asupan zat gizi sebelum dan setelah intervensi

\begin{tabular}{|c|c|c|c|}
\hline \multirow{2}{*}{ Asupan zat gizi } & Perlakuan $(n=31)$ & Kontrol $(n=32)$ & \multirow[b]{2}{*}{$p$} \\
\hline & Mean \pm SD & Mean \pm SD & \\
\hline \multicolumn{4}{|c|}{ Tingkat kecukupan energi (\%) } \\
\hline Sebelum & $79,6 \pm 19,84$ & $71,3 \pm 17,88$ & $0,161^{b}$ \\
\hline Setelah & $85,9 \pm 23,83$ & $82,1 \pm 18,74$ & $0.479^{\mathrm{a}}$ \\
\hline \multicolumn{4}{|c|}{ Tingkat kecukupan protein (\%) } \\
\hline Sebelum & $100,3 \pm 22,44$ & $104,7 \pm 26,74$ & $0,486^{\mathrm{a}}$ \\
\hline Setelah & $117,1 \pm 25,22$ & $107,7 \pm 25,07$ & $0,142^{\mathrm{a}}$ \\
\hline \multicolumn{4}{|l|}{ Energi (Kkal) } \\
\hline Sebelum & $1059,8 \pm 181,22$ & $1005,8 \pm 204,29$ & $0,272^{\mathrm{a}}$ \\
\hline Setelah & $1129,2+154,36$ & $1155,8+195,49$ & $0,563^{\mathrm{a}}$ \\
\hline \multicolumn{4}{|l|}{ Protein (g) } \\
\hline Sebelum & $31,7 \pm 7,59$ & $31,8 \pm 6,89$ & $0,937^{\mathrm{a}}$ \\
\hline Setelah & $37,3+7,87$ & $33,7+7,25$ & $0,063^{\mathrm{a}}$ \\
\hline \multicolumn{4}{|l|}{ Seng $(\mathrm{mg})$} \\
\hline Sebelum & $3,1 \pm 1,06$ & $3,2 \pm 0,84$ & $0,327^{\text {a }}$ \\
\hline Setelah & $4,1+1,04$ & $3,5 \pm 1,02$ & $0,037^{a^{*}}$ \\
\hline \multicolumn{4}{|l|}{ Besi (mg) } \\
\hline Sebelum & $2,8 \pm 1,44$ & $3,3 \pm 1,38$ & $0,226^{\mathrm{b}}$ \\
\hline Setelah & $4,5+1,49$ & $3,7+1,44$ & $0,036^{\mathrm{a}^{*}}$ \\
\hline \multicolumn{4}{|l|}{ Asam Folat $(\mu \mathrm{g})$} \\
\hline Sebelum & $57,4 \pm 24,71$ & $68,8 \pm 24,52$ & $0.072^{b}$ \\
\hline Setelah & $74,8+24,41$ & $63,9 \pm 28,32$ & $0,037^{b^{*}}$ \\
\hline
\end{tabular}

${ }^{\mathrm{a}}$ uji Independent t-test ${ }^{\mathrm{b}}$ uji Mann-whitney

Kelompok Perlakuan

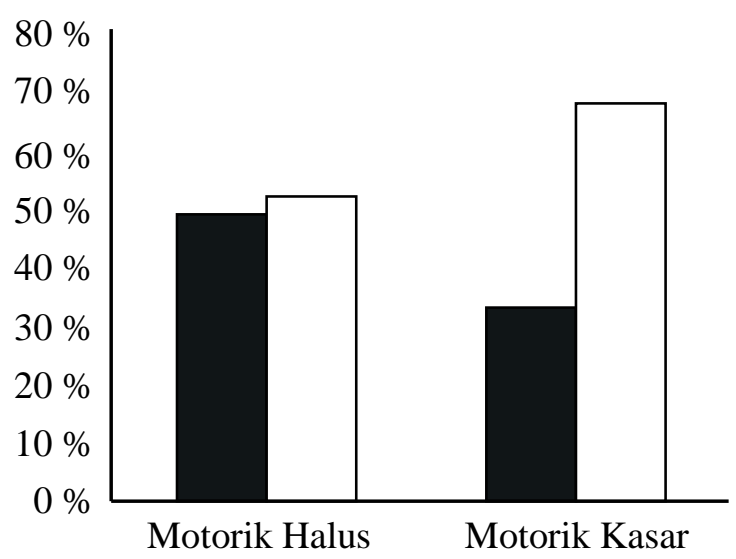

Kelompok Kontrol

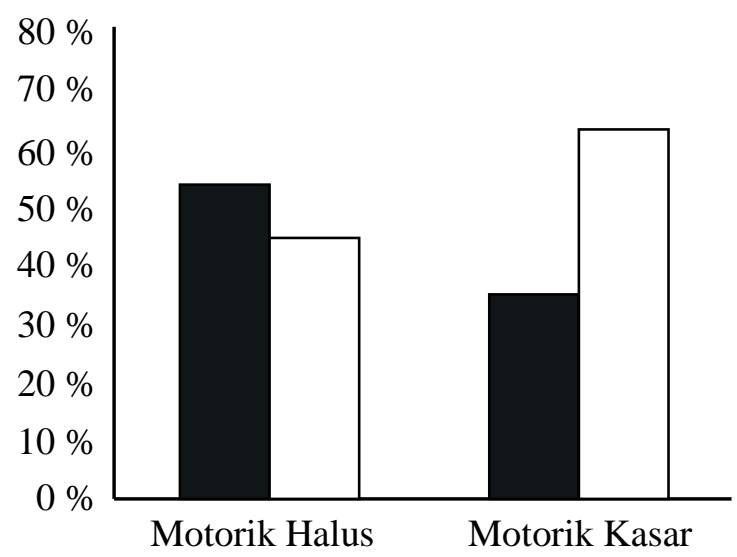

Gambar 2. Persentase Keterlambatan perkembangan motorik sebelum intervensi

Ket : $\square=$ Normal, $\square=$ Keterlambatan 


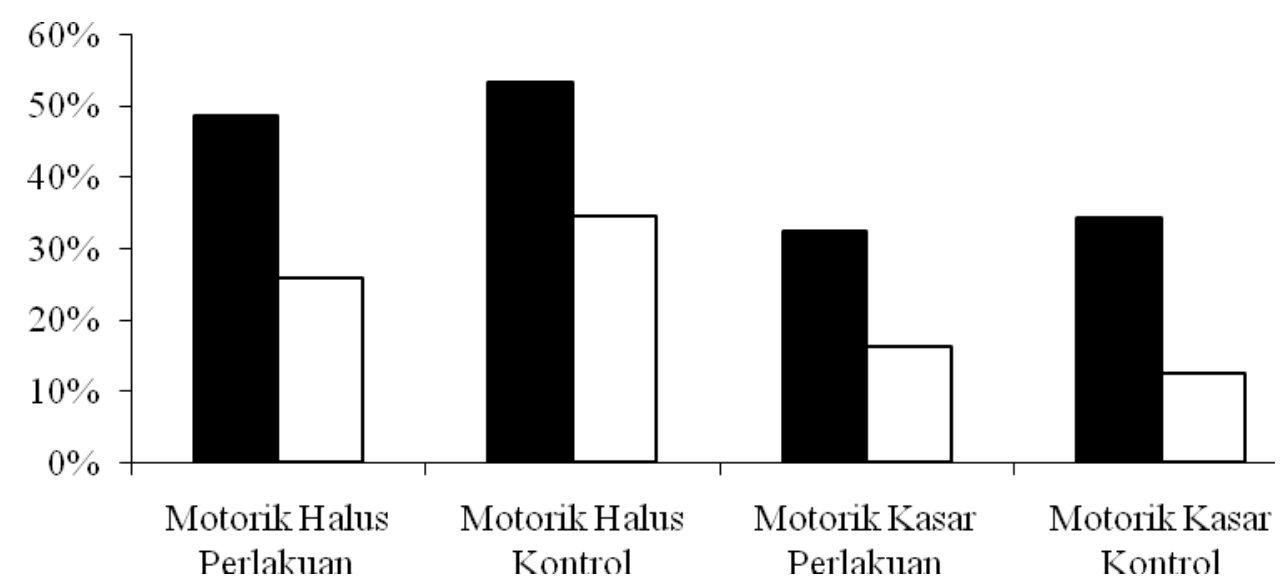

Gambar 3. Pengaruh intervensi terhadap persentase keterlambatan perkembangan motorik pada masing-masing kelompok. Ket : $\square=$ Setelah, $\square=$ Sebelum

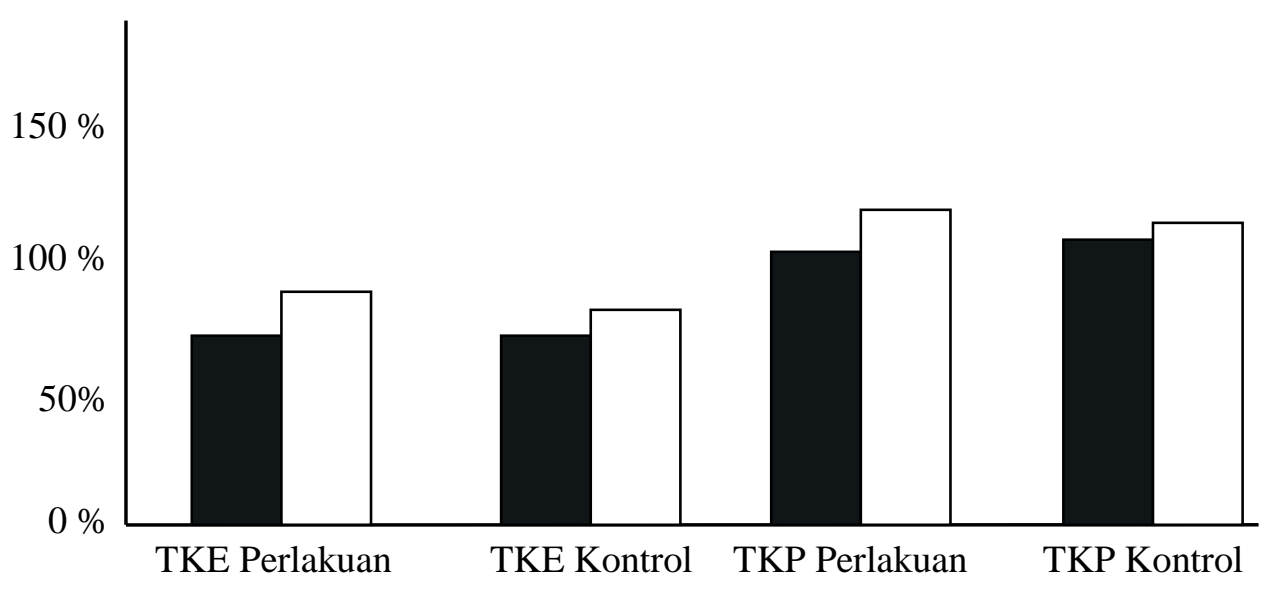

Gambar 4. Perbedaan tingkat kecukupan energi dan protein pada sebelum dan setelah intervensi antara kelompok perlakuan dan kelompok kontrol. Ket : $\square=$ Setelah, $\square=$ Sebelum

\section{PEMBAHASAN}

Tidak ada perbedaan persentase keterlambatan motorik halus $(\mathrm{p}=0,514)$ dan motorik kasar $(\mathrm{p}=0,571)$ setelah intervensi dan setelah dikontrol dengan variabel perancu. Tidak ada pengaruh pemberian micronutrient sprinkle dalam bentuk taburia pada kedua kelompok, baik kelompok perlakuan dan kelompok kontrol setelah dikontrol variabel perkembangan motorik sebelum intervensi. Tidak ada perbedaan perkembangan motorik halus dan motorik kasar pada kedua kelompok setelah pemberian intervensi taburia. Variabel tingkat kecukupan energi, tingkat kecukupan protein, asupan rata-rata seng, besi dan asam folat setelah intervensi bukan merupakan variabel perancu pada penelitian ini.

Beberapa penelitian terdahulu tentang pemberian suplementasi mikronutrien tidak menunjukkan hasil serupa dikarenakan usia subjek pada saat perlakuan adalah antara 5 bulan s/d 24 bulan. ${ }^{4,6,10}$ Pemberian suplementasi Suplementasi $\mathrm{Fe}+\mathrm{Zn}$ dan micronutrient mix pada anak berumur 6 bulan dan 12 bulan setiap minggu selama 6 bulan mampu meningkatkan skor rata-rata perkembangan motorik dibanding anak yang hanya menerima suplementasi $\mathrm{Fe}$ atau $\mathrm{Zn}$ saja. ${ }^{4}$

Penelitian di Ghana pada anak usia 5 bulan yang mendapat perlakuan micronutrient (micronutrient sprinkle/ Micronutrient nutritab/ Multiple micronutrient nutributter) setiap minggu selama tujuh bulan memiliki skor perkembangan motorik lebih baikdibanding yang tidak mendapat intervensi. ${ }^{6}$ Pemberian micronutrient sprinkle dengan nama Taburia pada anak stunting usia 12-36 bulan di kota Semarang selama dua bulan mampu menurunkan persentase keterlambatan perkembangan motorik halus. Pada penelitian tersebut rata- rata umur subjek kelompok perlakuan 23,3 bulan $\pm 6,70$ dan kelompok kontrol 24,4 bulan $\pm 6,51$, sedangkan pada penelitian 
ini rata-rata umur subjek kelompok perlakuan adalah 44 bulan $\pm 3,59$ dan kelompok kontrol 43,47 bulan $\pm 3,96 .{ }^{10}$

Taburia (micronutrient sprinkle) dimaksudkan untuk memenuhi kecukupan zat gizi mikro anak dan mengatasi permasalahan kekurangan gizi mikro terutama untuk baduta. Pemberian Taburia difokuskan pada balita dengan rentang umur 6 sampai 24 bulan dengan pertimbangan pada usia tersebut merupakan periode emas pertumbuhan. ${ }^{14}$ Hasil meta analisis pada 39 penelitian di negara berkembang menunjukkan bahwa status gizi seorang anak berdasarkan indeks berat badan menurut tinggi badan (BB/TB), penurunan status gizi dimulai sekitar usia 3 bulan hingga 15 bulan. Intervensi peningkatan asupan gizi dilakukan setelah anak berusia 2 tahun sangat tidak efektif karena kondisi anak sebenarnya mulai memburuk jauh sebelum anak berusia 2 tahun bersifat irreversible. ${ }^{15}$

Pemberian suplementasi micronutrient pada usia lebih dari 24 bulan memberikan hasil yang positif pada peningkatan status gizi anak. ${ }^{16}$ Pada keadaan normal, mielinasi pada daerah otak yang berhubungan dengan koordinasi tangan dan mata tidak lengkap hingga anak berusia sekitar empat tahun. ${ }^{8}$ Setelah anak berusia lebih dari empat tahun, pertumbuhan susunan saraf berlangsung lebih lambat. ${ }^{9}$ Pemberian suplementasi pada usia kurang dari empat tahun diharapkan dapat memperbaiki keadaan stunting dan mengoptimalkan potensi perkembangan motorik anak.

Perkembangan motorik anak erat kaitannya dengan perkembangan otak saat janin dan dua tahun pertama kehidupan. $^{8}$ Asupan energi, protein, besi, seng, tembaga, LC-PUFAs dan kolin yang adekuat membantu perkembangan otak secara optimal selain faktor genetik dan lingkungan. ${ }^{17}$ Pada penelitian ini aspek perkembangan mielinisasi dasar dan hasil yang sudah terbentuk tidak diketahui sebelum dilakukan intervensi.

Hipotesis penelitian ini tidak terbukti dikarenakan perbedaan lama durasi pemberian intervensi dengan penelitian sebelumnya. Beberapa penelitian terdahulu pemberian mikronutrien dilakukan dalam kurun waktu 6 s/d 12 bulan. ${ }^{3-6}$ Pada penelitian ini waktu yang digunakan untuk memberikan intervensi adalah selama dua bulan. Beberapa penelitian menyatakan bahwa zat besi mempengaruhi perkembangan motorik anak. $^{5,18}$ Suplementasi besi harian dan mingguan selama dua bulan meningkatkan kadar $\mathrm{Hb}$ dan besi serum secara signifikan.

Peningkatan kadar hemoglobin dapat dicapai sesudah intervensi selama 2 bulan, tetapi dianjurkan untuk meneruskan pengobatan sampai 5 bulan agar cadangan besi dapat terisi. ${ }^{19}$ Suplementasi besi selama 2 bulan dapat meningkatkan kadar hemoglobin dan besi serum secara signifikan pada anak umur 5-10 tahun. ${ }^{20}$ Anemia defisiensi besi berhubungan dengan perkembangan motorik anak. ${ }^{4,5,17}$

Ada pengaruh pemberian suplementasi seng dan besi terhadap perkembangan psikomotorik bayi anemia dan bayi dengan defisiensi seng usia 4-7 bulan yang mendapat intervensi selama 24 minggu di Indramayu Jawa Barat. ${ }^{18}$ Pada penelitian ini tidak dilakukan pemeriksaan kadar mikronutrien dalam serum sebelum dan setelah intervensi sehingga tidak diketahui subjek menderita anemia dan atau defisiensi seng.

Hasil sebuah meta analisis menyimpulkan bahwa intervensi multiple micronutrient dapat menghasilkan hasil intervensi yang lebih baik pada anak yang tinggal didaerah dengan defisiensi mikronutrien cukup tinggi. ${ }^{21}$ Pada penelitian ini belum dapat dipastikan bahwa Kecamatan Tanjungkarang Barat Kota Bandar Lampung merupakan daerah dengan defisiensi mikronutrien.

Faktor lain yang dianggap mempengaruhi penelitian adalah subjek dilatih oleh guru PAUD melakukan tugas-tugas perkembangan terstruktur menyerupai DDST II, sebelum pengukuran DDST II post intervensi dilakukan. Sehingga subjek lebih terlatih dalam melaksanakan kegiatan pengukuran perkembangan motorik pada pengukuran setelah intervensi, yang secara tidak langsung mempengaruhi hasil penelitian.

Faktor-faktor yang berhubungan signifikan dengan tingkat perkembangan motorik kasar dan motorik halus balita adalah status gizi balita, lama mengikuti PAUD dan usia balita. ${ }^{22}$ Dijumpai perbedaan yang sangat bermakna dalam perkembangan motorik pada kelompok yang mendapat stimulasi dengan alat permainan edukatif (APE) dan kelompok tanpa stimulasi. ${ }^{23}$ Anak usia 12-24 bulan yang mendapat stimulasi selama satu jam setiap hari selama tiga bulan memiliki peningkatan perkembangan lebih baik dibandingkan dengan anak yang tidak mendapat stimulasi. ${ }^{24}$

Variabel tingkat kecukupan energi, tingkat kecukupan protein, asupan rata-rata seng, besi dan asam folat setelah intervensi bukan merupakan variabel perancu pada penelitian ini. Hasil ini tidak sesuai dengan penelitian lain yang menyatakan bahwa rata- rata asupan energi dan asupan protein mempengaruhi kemampuan motorik anak. ${ }^{25}$ Energi, protein, seng dan zat besi merupakan zat gizi yang memegang peranan penting dalam perkembangan motorik anak. Energi dan protein berperan dalam proses proliferasi, diferensiasi sel dan synaptogenesis. ${ }^{17}$ Ketersediaan energi mempengaruhi aktivitas fisik anak, dimana aktivitas berkorelasi erat dengan perkembangan motorik. ${ }^{26}$

Protein yang terbentuk oleh asam amino merupakan sumber asam amino yang diperlukan 
tubuh yang berfungsi sebagai katalisator, pembawa, pengatur, penguat struktur, imunitas, dan pertumbuhan. Penelitian kohort pada bayi di pedesaan Guatemala diperoleh hasil bahwa asupan protein hewani dari makanan pendamping ASI berhubungan dengan kemampuan berjalan anak. ${ }^{27}$ Asam amino tirosin merupakan jenis asam amino yang berhubungan dengan mekanisme gerak motorik dimana tirosin merupakan penyusun dari neurotransmitter dopamine yang berperan dalam menghantarkan impuls dari satu saraf ke saraf lain. ${ }^{28}$

Besi berperan dalam sintesis monoamine, metabolisme energi di neuron dan sel glia, serta mielinisasi. ${ }^{17}$ Defisiensi besi berhubungan dengan penurunan aktifitas pada anak, karena defisiensi besi pada anak menyebabkan keletihan, keragu-raguan, ketakutan dan kelelahan. ${ }^{26}$ Suplementasi besi pada bayi di Purworejo dengan dosis $10 \mathrm{mg}$ setiap hari selama enam bulan mampu meningkatkan skor ratarata perkembangan motorik anak dibanding kelompok kontrol. $^{5}$

Berdasarkan baseline data tingkat kecukupan energi dan tingkat kecukupan protein (Grafik 4) terjadi peningkatan asupan energi dan protein terutama pada kelompok perlakuan setelah intervensi. Peningkatan asupan zat gizi itu mungkin karena nafsu makan yang meningkat akibat pemberian mikronutrien sebab peningkatan asupan energi dan protein secara langsung mempengaruhi tingkat kecukupan energi dan tingkat kecukupan protein secara statistik bermakna pada kelompok perlakuan dengan nilai $p$ berturut turut $p=0,001$ dan $p=0,015$.

Peningkatan persentase pemenuhan angka kecukupan gizi mempengaruhi status gizi anak. Pada penelitian ini tidak dilakukan pengukuran status gizi setelah pemberian intervensi untuk melihat perubahan status gizi anak.

Peningkatan nafsu makan sebagai efek dari pemberian micronutrient sprinkle. Salah satu zat gizi mikro yang terkandung dalam micronutrient sprinkle yaitu seng. Asupan seng yang tercukupi mampu meningkatkan nafsu makan, karena mineral seng meningkatkan ketajaman indra perasa sehingga membuat anak menjadi lebih cepat lapar dan meningkatkan asupan makan anak. ${ }^{28}$

Kaitan seng dengan perkembangan motorik anak adalah seng berperan dalam sintesis DNA dalam jaringan otak, pertumbuhan otak, konsentrasi RNA, protein otak dan pelepasan neurotransmitter. ${ }^{29}$ Defisiensi seng kronis mengganggu fungsi optimal pusat system saraf dan otak. Seng diperlukan untuk metabolisme monoamin oksidase, yang berperan dalam fungsi neurotransmiter. ${ }^{30}$ Defisiensi seng menurunkan aktivitas anak karena meningkatkan resiko morbiditas sehingga mempengaruhi perkembangan motorik anak. ${ }^{4}$
Perkembangan motorik dipengaruhi perkembangan otak yang dimulai saat anak masih di dalam kandungan dan dua tahun pertama kehidupan. Intervensi berupa pemberian micronutrient dapat dilakukan pada saat persiapan kehamilan, pada saat kehamilan dan pada bayi usia dibawah dua tahun (baduta).

\section{SIMPULAN}

Dari penelitian ini dapat disimpulkan bahwa pemberian micronutrient sprinkle selama dua bulan tidak mempengaruhi perkembangan motorik halus dan motorik kasar pada anak stunting usia 24 hingga 48 bulan yang mengikuti PAUD setelah dikontrol dengan variabel perancu.

\section{DAFTAR PUSTAKA}

1. Mc Gregor SG, Henningham B. Review of the evidence linking protein and energy to mental development. Public Health Nutr 8. 2005:11911201.

2. Paiva MD, Souza TO, Canon F, Pérot C, Xavier LC, Ferraz KM. Stunting delays maturation of triceps surae mechanical properties and motor performance in prepubertal children. Eur J Appl Physiol 2012;112:4053-61.

3. Harapap, Jahari AB, Husaini MA. Effect of an Energi and Micronutrient Supplement on Motor Development and Motor Activity in Undernourished Children in Indonesia. Europan Journal of Clinical Nutrition. 2000.

4. Black MM, Baqui AH, Zaman K. Iron and zinc Supplementation Promote Motor Development and Exploratory Behavior among Bangladeshi Infants. The American journal of clinical nutrition. 2004;80:903-10.

5. Lind T, Lönnerdal B, Stenlund H, Gamayanti IL, Ismail D, Seswandhana R, and Persson LA. A community-based randomized controlled trial of iron and zinc supplementation in Indonesian infants: effects on growth and development. Am J Clin Nutr 2004;80: 729-36.

6. Afarwuah SA, Lartey A, Brown KH, Zlotkin S, Briend A, Dewey KG. Randomized Comparison of 3 Types of Micronutrient Supplements for Home Fortification of Complementary Foods in Ghana: Effects on Growth and Motor Development. American Journal of Clinical Nutrition, Vol. 86, No. 2. 2007;412-420.

7. Direktorat Bina Gizi Masyarakat. Apa dan Mengapa Tentang Taburia; panduan praktis bagi kader. Dijen Binkesmas-Kemenkes RI. Jakarta. 2010. 
8. Santrock JW. Child Development Ed.11 McGraw-Hill Higher Education. 2007.

9. Hurlock EB. Psikologi Perkembangan: Suatu Pendekatan Sepanjang Rentang Kehidupan. Jakarta: Erlangga. 2008.

10. Purwandini K, Kartasurya MI. Pengaruh pemberian Micronutrient Sprinkle terhadap perkembangan motorik anak stunting usia 12- 36 bulan. Journal of Nutrition College. Volume 2. No 1. 2013; 147-163.

11. Badan Penelitian Dan Pengembangan Kesehatan Kementerian Kesehatan RI. Riset Kesehatan Dasar 2010. Laporan Nasional. 2010. p 26, 29, 30.

12. Dinas Kesehatan Kota Bandar Lampung. Data Seksi Gizi Dinas Kesehatan Kota Bandar Lampung tahun 2012.

13. Gardner JMM, Powell GA, Henningham HB, Walker SP, Cole TJ, McGregor SMG. Zinc Supplementation And Psychosocial Stimulation: Effects On The Development Of Undernourished Jamaican Children. Am J Clin Nutr 2005;82:399-405.

14. Departemen Kesehatan RI. 2011. Pengembangan Taburia. diakses tanggal 9 April 2013. http://gizi.depkes.go.id/artikel/pengembangantaburia/.

15. Shrimpton, Victoria CG, deOnis M, Lima RC, Blossner M, Clugston G. Worldwide timing of growth faltering: implications for nutritional interventions. Pediatrics 2001; 107: e75.

16. Sazawal S, Dhingra U, Dhingra P, Hiremath G, Kumar J, Sarkar A, Menon V, Black R. Effects of fortified milk on morbidity in young children in north India: community based, randomised, double masked placebo controlled trial. BMJ. 2007;334:140.

17. Georgieff MK. Nutrition and Developing Brain: Nutrient Priorities and Measurement. Am J Clin Nutr.85. 2007; 614S-20S.

18. Purwaningsih E. Pengaruh suplementasi seng dan besi terhadap pertumbuhan perkembangan psikomotorik dan kognitif bayi: uji lapangan di Indramayu Jawa Barat. Bunga rampai topik gizi sesi I. Badan penerbit UNDIP. 2008 Hal 1-13.

19. Raspati H, Reniarti L, Susana S. Anemia defisiensi besi. Dalam: Permono B, Sutaryo, penyunting. Buku Ajar Hematologi-Onkologi Anak, Jakarta: Badan Penerbit IDAI; 2005. h. 3043.
20. Siddiqui IA, Rahman MA, Jaleel A. Efficacy of daily vs weekly supplementation of iron in school children with low iron status. J Trop Pediatr 2004;50:276-78.

21. Ramakrishnan U, Goldenberg T, Allen LH. Do Multiple Micronutrient Interventions Improve Child Health, Growth, and Development? J. Nutr. 141: 2066-2075, 2011.

22. Megawangi R, Hastuti D. Pendidikan holistik berbasis karakter pada anak usia prasekolah dan pengaruhnya pada pembentukan anak tumbuh sehat, cerdas, dan berkarakter [laporan]. Bogor: Duelike Project IPB. 2005.

23. Sari LP, Saing B, Lubis IZ. Hubungan antara Alat Permainan Edukatif dan Perkembangan Motorik Anak pada Taman Penitipan Anak, Majalah Kedokteran Nusantara Volume 39. No. 1. $\square$ Maret 2006.

24. Irmawati M, Ardani IGA, Astasari D, Irwanto, Suryawan A. Pemberian stimulasi selama satu jam pada perkembangan anak usia 12-24 bulan. Media Medika Indonesia Volume 46. N0.3. 2012.

25. Kartika V \& Latinuhu S. Faktor- faktor yang mempengaruhi kemampuan motorik anak usia 12- 18 bulan di keluarga miskin dan tidak miskin. PGM.25 (2)2002 : 38-48.

26. Husaini MA, Jahari AB, Husaini JK, Widodo Y. Normal Motor Milestone Development for Use to Promote Child Care. Paediatrica Indonesiana. Vol. 50, No6. 2010.

27. Kuklina EV, Ramakrishnan $U$, Stein AD, Barnhart HH, Martorell R. Growth and Diet Quality are Associated with the Attainment of Walking in Rural Guatemalan Infants. J Nutr.2004;134: 3296-3300.

28. Westermack T, Antila E. Diet in Relation to the Nervous System. In Garrow JS, James WP, Raplh A, editors. Human Nutrition and Dietetik. $10^{\text {th }}$ edition. New York: Chuchill Living Stone; 2000.

29. Shakur MS, Bano N. Effect of Zinc Supplementation on Appetite, Growth \& Body Composition in Children Suffering From NonSpecific Etiology of Feeding Refusal with Failure to Thrive. The ORION Medical Journal 2009 Jan;32(1):612-615.

30. Sandstead HH, Frederickson CJ, Penland J.G. History of Seng as Related to Brain Function. J.Clin.Nutr. 2000.p 130:49 